\title{
神経性ドライマウスの捉え方と対処法
}

\section{豊福明 \\ Psychosomatic approach for dry mouth associated with neurogenic or neuropsychiatric disorders}

\author{
TOYOFUKU Akira
}

\begin{abstract}
In dry mouth clinic, there are many patients who complained of subjective feelings of dry mouth despite their normal salivation. This dry mouth frequently comorbid with glossodynia or oral dysaesthesia. So far, these complaints have been thought to be 'psychogenic'. Namely, psychosocial factors and/or individual factors have long been considered as main cause. Even if oral surgeons referred patients to psychiatry clinic, a majority of them wished to avoid consultation, or, would sometimes complain that the dry mouth got worse after medication. Therefore, it is very important and difficult problems for clinical oral surgeons to see how look at these patients and to learn how cope with them.

From my own years of experience in psychosomatic studies, I think 'distorted cognition' is central to these pathogenesis. These distorted cognition cause dissociations between subjective and objective findings. Moreover, I have propose a hypothesis that neurochemical dysfunction of some sort of neurotransmitter systems and distortions of information-processing in cerebral association area related to thought and memory underlie the distorted cognition.

Patients with subjective dry mouth never tell a lie about their symptoms, but they have just 'neural network error' in their brain. We should take up to problems of oral discomfort at the root of their complaint.

If we suspect their complaints as the cause of psychogenic, it might be often unsuccessful in treatment. First of all, to listen carefully to complaints from them is very important, and then we have to do differential diagnosis. If patients are diagnosed the symptom form with distorted cognition, medication using SSRI or SNRI is necessary for reconstruction of impaired neuronal network. Of course oral surgeons have to receive advanced education and training to use psychotropic drugs. At the same time, it is needed for sensitive response to patients and family members.
\end{abstract}

The distorted cognition with these patients are associated with dysfunction of neurotransmitter systems and information-processing in peripheral to higher central nervous system. Strange complaints and persistent therapeutic demand are representatives of the distorted cognition. If we regard queer complaints as neural network errors, we can see the psychogenic complaints as distorted cognition.

At present, this hypothesis cannot be shown objectively, but it might be possible that some new approaches such as brain imaging make mechanisms of the distorted cognition more clear. It is very important to collect evidence-based diagnosis, therapies and pathophysiological mechanism for dry mouth as an oral psychosomatic disorder.

Key words: dry mouth associated with neurogenic or neuropsychiatric disorders（神経性ドライマウス), psychogenic (心因性), oral psychosomatic disorder (㐘科心身症), distorted cognition（認知の歪み）

東京医科柬科大学大学院医茵学総合研究科柬科心身医学分野

Psychosomatic Dentistry, Department of Comprehensive Oral Health Care, Division of Comprehensive Patient Care, Graduate School, Tokyo Medical and Dental University

\section{は じめに}

「神経性ドライマウス」の定義は難しい. 従来この用語 は, 延髄疾患, 脳腫瘍, 顔面神経の障害や自律神経失調な どによる分泌神経障害と, 精神障害や精神的興奮, 緊張な 
どの精神的原因といった精神・心理的要因によるドライマ ウスを総称して用いられてきた ${ }^{1)}$.このような病態は厳密 な区別が病理組織学的には難しい故に, 目に見えない病気 特有の混乱が生じやすかった面は否めない.しかし, 神経 内科と精神科は独立した領域として確立している. 今後は ドライマウスも neurological（神経学的）な原因によるも のと, psychiatric（精神科的）な原因によるものとに整理 されていくものと予想される.

ところで「ドライマウス外来」では, 唾液分泌量は正常 範囲内であるにもかかわらず,「口腔乾燥感」「ネバネバ, ベタベタ感」を訴えて受診する患者が相当数存在すること が知られている ${ }^{2)}$. このような患者には舌痛症や口腔異常 感症などとの comorbidity もかなりの頻度でみられる. 各 種検査上でも特に異常は認められず，その旨をいくら説明 しても「でも不快でたまらないのです」と訴えられ，対応 に苦慮することがしばしばある.

従来, このような病態は「自覚的口腔乾燥感はあるが, 他覚的口腔乾燥症状と唾液分泌量の減少がない」ため, 「心因性」とされ ${ }^{3)}$, 性格や生い立ちの問題や人間関係な どの心理社会的因子が原因として挙げられたり，うつ病な どの精神障害が背景にあるなどと説明され, 治療としては 精神科や心療内科などへ紹介が第一とされてきた ${ }^{1)}$.とこ ろがそれらの科に紹介しようとしても患者が受診を忌避し たり，ようやく受診したかと思えば「特に問題ないと言わ れた」と戻ってきたりする. あるいは処方された向精神薬 によって「かえってロが渴くようになった」と訴えられ， さらに対応に苦慮することすらある.

このような患者をどう捉え, どう対応するかは現場の口 腔外科医にとって切実な問題となっている. 本稿では臨床 上特に問題となりやすい，いわゆる「心因性ドライマウス」 について概説したい.

\section{「心因性」という用語について}

前述のように訴えに相応する局所所見もしくは検査所見 に乏しい愁訴には，しばしば「心因性」のレッテルが貼ら れる。しかし，「非器質性」もしくは「原因不明」の症状 が即「心因性」とは言えないことに若干の注意が必要であ る. 症状を説明できる「心因」(例えば著しい精神的ショ ック体験や深層心理など）が特定できて初めて「心因性」 である。それは精神科専門医にとってもしばしば特定困難 な場合がある。ささらに患者も口腔症状を「心理的なもの」 と見做されることに不満や抵抗を隠さないことが多い.

一方でいわゆる「心因性ドライマウス」は純然たる精神 障害とも言えない場合が多い. 統合失調症やうつ病など重 症の精神障害患者が, 口腔乾燥を訴え口腔外科を受診して
くることは案外少ないのも臨床的事実である.すなわち 「精神科任せにできない」のに客観的所見に乏しい「口腔 領域の愁訴」であるがゆえに口腔外科の臨床現場での対応 を困難にすると言える。

\section{身体表現性障害という診断名の問題点について}

これらの患者は精神科では「身体表現性障害」4, 5) と診 断されることがほとんどである。しかし，身体的に問題が ないとして精神科へ紹介されてくる患者のなかには「精神 科的にも問題がない」としか返事の仕様がない患者も含ま れているという ${ }^{4)}$.

「身体表現性障害」とラベル付けされた患者に対する治 療的方策に関しては, 精神科医からも柬切れの良い返答は 帰ってこないことが多い ${ }^{4}$ - 6). 心の専門家にとっても, 口 腔に関する即物的な愁訴に終始しがちな患者の話に耳を傾 け続けることはなかなか難しいようである。「身体表現性 障害」と診断されたものの, 精神科より身体科で継続診療 されていることで安定が得られている患者はかなり多いと いわれている4).

またこのような病名によって, 明確な器質的異常が認め られない症状は, 須らく「心因性」と短絡的に決め付けら れる危険性がある。さらに家族や医療スタッフ間に「本物 の症状」と「気のせい」という二元論的思考を奨励しやす $\iota^{7)}$.

丸田 ${ }^{7)}$ は「心因性 vs 器質性」という区分は，「少なく とも慢性疼痛の臨床では意味を持たない」,「“medically and psychiatrically unexplained pain”をめぐる議論を支配 するのは, 文献, evidence, research data」という装いの下 で語られる, 個人的な思い込み, 価值観, 確信, (患者に対 する）情緒的反応であることが少なくない」と看破してい る.ドライマウスの臨床に扎いても，この卓見は正鵠を射 ていると思われる。

このような患者が認知する「歯」や「口」が, 客観的な 口腔内所見とは違うことは周知のところである. 患者がそ の症状を体験している「身体」は神経学的な意味での身体 から少しずれている ${ }^{8)}$.

「医学的に説明できない」と規定される身体表現性障害 の術語は, 結局のところ心因性であるという含意を有する ため患者には受け入れ難い病名で, 治療導入を困難にす る ${ }^{4,5)}$.

「私の病気は精神的なものではない」と主張する患者と コミュニケートするには, まずは脳内の心的表象 ${ }^{9,10)}$ と しての「身体」に焦点を合わせる必要がある. 医学的に説 明ができるかどうかに関わらず，「病気」という体験，心 的表象にはかわりがないかもしれないからである. 


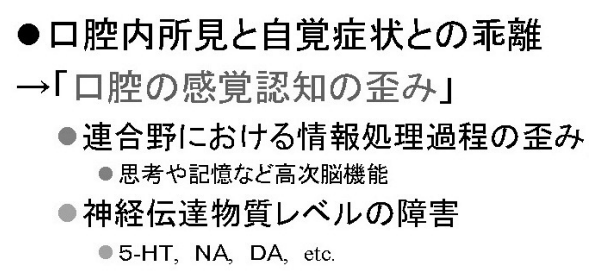

患者はウソをついているのではなく、脳の中で 「そう感じるようなエラー」が生じている

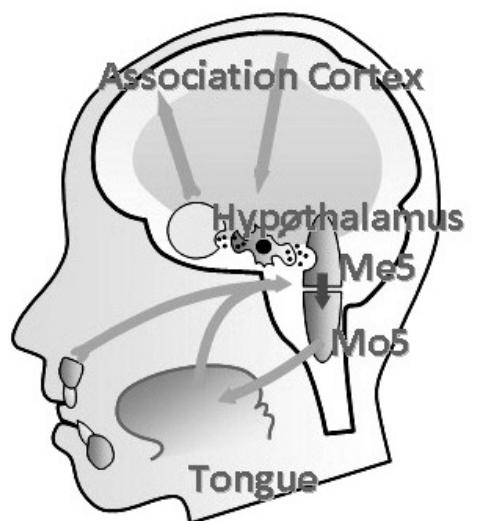

の病態仮説

\section{患者の訴えをどう捉えるか？}

本稿では「心」を「意識, 感情, 認知過程のすべてを含 む，午の個体に生じているであうう主観的現象の総体」と， 「認知」を「感覚受容から意味の照合までの脳内情報処理 過程」と定義し ${ }^{11)}$ ，論考を進めていく．

著者はこれまでの一連の茵科心身医学的研究から ${ }^{11,12)}$ このような客観的所見と主観的症状の乘離には, これらの 患者に特有の「感覚認知の歪み」が病態の中核をなすので はないかと考えてきた，さらに本症の病態仮説として「脳 内の神経伝達物質系に関する生化学的異常」と「思考や記 憶などに関する大脳皮質連合野に打ける情報処理過程の歪 み」という 2 つの側面を想定してきた（図 1).

このような患者の問題は, 末梢から高次中枢にまたがる 情報伝達系や情報処理機構の障害にある. 一見奇異に聞こ える患者の訴え，あるいは執拗な治療要求，これらがその 表現型である. 歪んだ感覚認知や概念認知はこれらを結実 させる「心因」の中核にある. 本症を脳機能の微細なエラ 一として捉えようとすれば，「心因」を「認知の歪み」と して理解し, 病態の中核に位置づける方が今後の解明は進 めやすい.

すなわち本症患者はウソをついているのではなく, 脳の 中で「方感じるようなエラー」が生じていると言える. よって治療に打いては, 訴えの根底にある口腔感覚異常の 問題を取り上げる必要がある. 口腔症状に軸足を置き, 脳 機能を見据えると, 心理機制や性格を持ち込む必然性は少 ない訳である.

\section{Brain imaging への期待と Individual variation $の$ 問題}

茵科心身症のような, 脳機能システムの障害という側面
が強い疾患では, 神経回路網（ニューラル・ネットワーク） の構造やそれらの接続パターンに病態の本質が潜んでいる ことは間違いないであろう ${ }^{9,10)}$.

ところが, 未梢から高次中枢にまたがる情報伝達系や情 報処理過程の障害をどう捉えるかが問題である. 認知の歪 みは, 現在のところ血液検査や画像では捉え難い症状では ある。

近年, Positron Emission Tomography（陽電子放射断層 撮影 PET) や functional Magnetic Resonance Imaging（機 能的磁気共鳴画像 fMRI) など脳活動を画像化する手法 が発達してきた。また, Statistical Parametric Mapping (SPM) など画像統計解析ソフトゥェアの確立によって, 各スキャン間での頭部の動きの補正や各個人の脳を標準脳 に変換する spatial normalizationや, ノイズを減少させボ クセルごとの検定を行いやすくするための平滑化 smoothing などの画像処理を経た統計处理, さらには統計処理で 得られた有意な賦活部位のデータを平均化させて作られて いる 3 D 脳画像に貼り付けることが可能となった ${ }^{13)}$. ま た, 同一のタスクやパラダイムを行った数人の被験者のデ ータをグループとして扱い, 共通した賦活領域の特徴を見 出すことも可能となった.

さまざまな技術的制約から脳機能画像所見で検出された 異常も病気の原因なのか結果なのかの解釈が難しいという 問題はある.しかし, 将来的には病歴や愁訴のみならず, このような客観的指標に基づいた診断や治療の評価に関す るデータを積み上げて検討していくことが肝要であろう。

まだ十分なデータが蓄積されているわけではないが, 我々は現在まで 10 数例の菌科心身症の Single photon emission computed tomography (単一光子放射断層撮影 SPECT）による脳血流評価を行ってきた. 図 $2 ， 3$ にその 一部を提示するが, 年齢, 性別, 臨床的重症度など臨床的 には可及的に均質な病態の患者を集めたつもりでも, 患者 

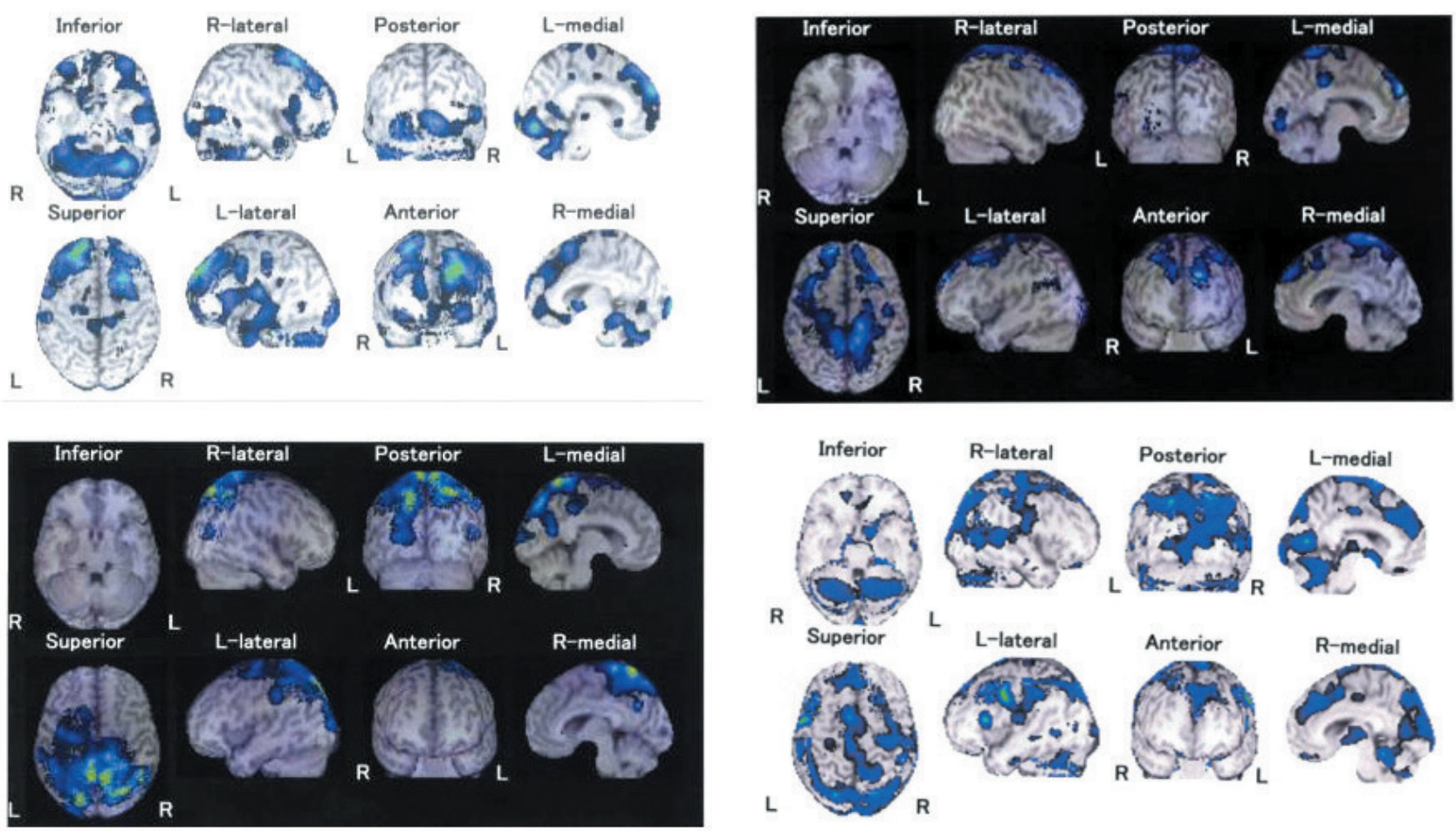

図 2 初診時の舌痛症患者の ${ }^{99 \mathrm{~m}} \mathrm{Tc}-\mathrm{ECD} \quad \mathrm{SPECT}$ 解析

臨床的には同様な舌痛症でも, 脳血流シンチにおける個人差が大きい,

症例A
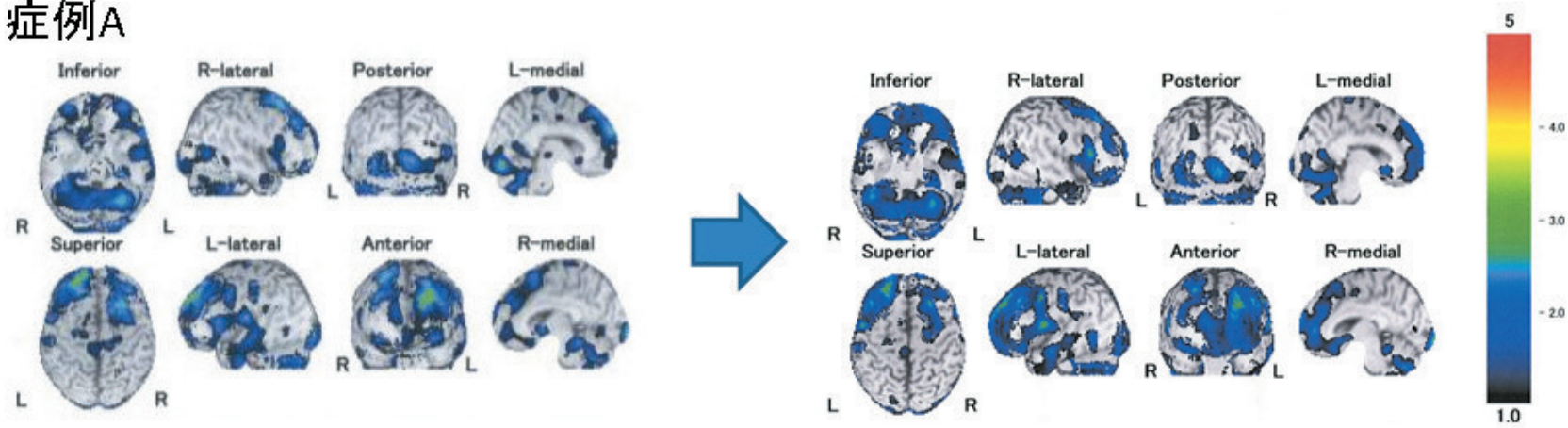

\section{症例 $B$}
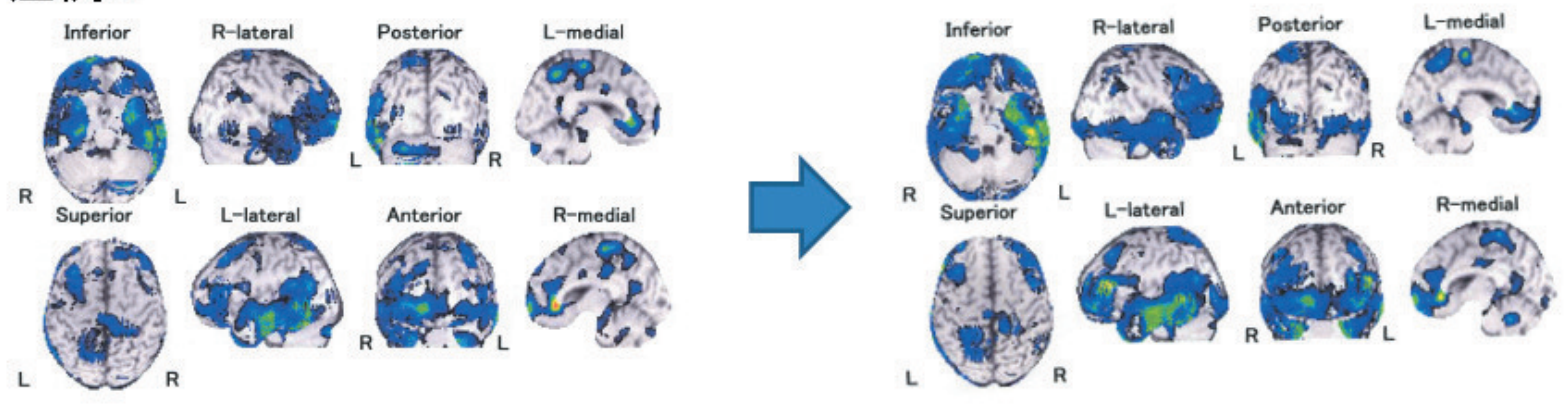

図 3 治療前後の比較

薬物療法にて舌痛の改善後に follow-up study を行っても，自覚症状の改善と脳血流の变化の間に一定の傾向は見 いだせていない， 
ごとに regional cerebral blood flow（局所脳血流量 rCBF） のパターンが大きく異なっていることが一目瞭然である. まだ即断は禁物ではあるが，これらの結果から我々は必ず しも均一な患者群を見ているわけではない可能性があるこ とに注意すべきかもしれない. 単一の疾患に複数の神経回 路の変容が関与していて, その生物学的基盤が個人ごとに 根本的に異なっている可能性, すなわち脳内の異なった神 経回路から同一の症状・愁訴が生じる可能性も想定される 訳である ${ }^{9,10)}$. またそう考えると, 本症患者間の症状の微 妙なバリエーション, 薬剤の反応性, 忍容性, 副作用の出 現に個人差が大きいことの説明がつきやすい.

「自覚的口腔乾燥感はあるが, 他覚的口腔乾燥症状と唾 液分泌量の減少がない」患者を「心因性ドライマウス」も しくは柬科心身症と一括した場合, 患者の訴え（表現型） は同一でも, 脳内で生じている現象はむしろ非常に heterogeneous な集団を診ている可能性が高くなる.

昨今, 遺伝率の研究で問題になっているように ${ }^{14)}$, 研究 方法の精緻化によってありふれた疾患と言われるものが, 実際には千差万別の疾患を包含していることが判明するか もしれない.

特に主観的症状の解明に関しては, Christof Koch ${ }^{9)}$ の 「脳内のニューロンの異なる 2 つの状態が主観的には判別 不能なことがあるかもしれない」, Gerald M. Edelman ${ }^{10)} の$ 「意識とその原因となる神経回路とは一対一対応ではなく, 一対多対応らしい」といった洞察にヒントが隠されてい るように思われる.

\section{臨床現場では，どう対処するか？}

前述のように本症患者の口腔症状に軸足を置き, 脳機能 を見据えると, ドライマウス診療に患者の心理機制や性格

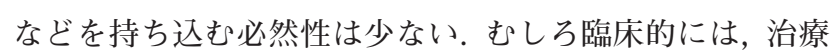
者側が抱く「心理的なもの」という先入観が反治療的に作 用する場合が少なくない.

まずは患者の訴えを傾聴した上で, 必要な除外診断を行 うことまでは誰もが実践しているであろう。さらにもう一 歩踏み込んだ治療をということになれば, Selective Serotonin Reuptake Inhibitor（選択的セロトニン再取り込 み阻害薬 SSRI）や Serotonin-Noradrenaline Reuptake Inhibitor（選択的セロトニン・ノルアドレナリン再取り込 み阻害薬, SNRI）など脳内神経伝達物質を調整する薬郕の 処方が必要となる ${ }^{15)}$.

患者の心理的抵抗と抗うつ薬独特の使いゔらさから, 口 腔外科領域では古くからその効果は知られているにもかか わらず 16) 抗うつ薬治療が普及しているとは言い難い ${ }^{17,18)}$. 結果として意味のない検査や効果のない保湿剤や哈嗽剂の
処方, もしくは柬科的処置の繰り返しといった治療の本質 に導入できないままの対応を強いられる事態がしばしば生 じている.

\section{薬物療法の勘どころ}

これらの向精神薬の効果については, その薬理作用のみ ならず「それがどのような文脈で使用されたか」が大きな 因子であることが分かっている ${ }^{19)}$. 単に「うつのクスリ」 として処方されるか，「口腔内の不快感を軽減するために」 と説明され納得の上で服薬するかでは, 治療結果が大きく 変わってくる. 処方に際してきめ細かい説明と納得が大切 な所以である.

一方, 向精神薬の効果・副作用から鑑みると案外, 身体 は正直でもある. どんなに患者が期待して服薬しても副作 用で中断せざるを得ないこともあるし, 半信半疑でしぶし ぶ服用した患者が劇的に改善することもしばしば経験され る.すべてがプラセボ効果で説明できるほど簡単でもな い20).

抗うつ薬は抗菌薬や消炎鎮痛薬のような一律な効き方は しない ${ }^{21)}$. 効果発現の個人差や特有の副作用などを勘案し ながら薬剤選択や用量確定をしていく必要がある。「抗う つ薬だからうつに効いている」わけではない22). 㐘科心身 症はうつ病と異なり, 抗うつ薬への忍容性が極端に低く, 副作用も生じやすい. このような薬剤の副作用を抑えつつ, 最大の効果を生むための処方技術には高度の専門知識の みならず患者や家族への肌理細かい詨応も必要とされ る $15,23,24)$.

現在のところ, 本症の治療は, 口腔外科医自身が向精神薬 の処方に精通することと, 患者への心理的対応がポイント になると思われる.リエゾン診療が期待された時期もあっ たが, 精神科的治療の予後から心身二元論的アプローチの 限界も示唆されている ${ }^{4)}$. 本症の心理療法は必ずしも精神 分析的である必要はなく, 薬物療法の効果を確認しながら, 日々の診療のなかで生じる具体的な問題を話し合うことに よって患者の認知や行動の修正を図ることが要諦となる.

\section{患者対応上の注意}

患者は口腔内の愁訴をもって口腔外科を受診する.すな わち患者は「器質的な問題」と考えている, ということに 少し配慮が必要である. 先入観を含んだ対応は, 本当に心 因性のものかどうかという問題以前に「診察の態度が悪い」 というレべルで医師一患者関係を損ねてしまうからであ る.

結局, 臨床の現場で患者に伝わっているものは何であろ 
うか？それは，その患者のためにかけた時間，一生懸命さ， 丁寧さ, などであり, 実は筋の通った科学的, 合理的説明 ではない，それらの evidence level がいかに高からうと，当 の患者本人にとっては全く合理的説明とはならないからで ある.「この先生はどのくらい私の困っている症状を心配 してくれているか？」「真剣に対応してくれているか？」 を患者はいつも気にしている.

本来，医療というものは患者のために存在するものであ り, 器質的障害の有無を問わず, 患者の身体的悩みを解決 するのが真の医療の目的である.いわゆる「心因性ドライ マウス」患者の存在は, このことを改めて我々に思い起こ させてくれる.

\section{ま と め}

神経性ドライマウスの臨床的ニーズは高い. 特に歯科心 身症に包含された，いわゆる「心因性ドライマウス」の病 態解明, 治療技法の確立, モデル医療の開発が望まれてい る.

患者は，日常生活や業務の困難といった不利益を被って いることも多く, 社会的な損失としても医療費の問題から しても看過できない.これらの患者に特有の客観的所見と 自覚症状の乘離には, 脳内情報伝達系や情報処理機構の障 害が想定される.このような病態に対しては従来の精神疾 患分類に頼るよりも ${ }^{24)}$, 口腔の「感覚認知の歪み」として 捉えた方が, 臨床的にも好ましく, 今後の病態解明も進め やすい ${ }^{25)}$. 将来的には個人差も含めた本症の脳内機構の病 態解明と治療法の発展が期待される.

\section{謝辞}

本研究は, 平成 $18 \sim 20$ 年度日本学術振興会科学研究補助 金（基盤研究 C 18592295）の助成を受けた.

\section{引用 文 献}

1）篠原正德：ドライマウス治療の実際. 斎藤一郎 監 修：「ドライマウスの臨床」, 医柬薬出版, 東京, 2007, 106-121 頁.

2) 中川洋一：ドライマウスの臨床一ドライマウス外 来での対処 一. 日外誌 55: 11-18 2009.

3) 日本口腔粘膜学会用語 - 分類検討委員会作成; 口腔 乾燥症（ドライマウス）の分類 一 日本口腔粘膜学 会案一. 日口粘膜誌 14: 87-88 2008.

4）野口正行：身体表現性障害一骖療上の諸注意とそ の診断分類の問題点 - . 精神科治療学 23: 41-46 2008.

5）加藤 敏：身体表現性障害. 武田雅俊, 加藤 敏, 神庭重信 著：Advanced Psychiatry 脳と心の精神
医学, 東京, 金峰堂, 2007, 75-115 頁.

6）宮岡 等, 鈴木志摩子 : 慢性疼痛はどう診断されて きたか. 精神科治療学 15: 243-250 2000.

7）丸田俊彦：痛久の精神医学. 臨床精神薬理 10: 1911962007

8）笠原 嘉: 二つの身体. 精神療法 22: 3-4 1996.

9）クリストフ・コッホ：意識の探求 神経科学からの アプローチ（下)，岩波書店，東京，2006，555-578 頁.

10）ジェラルド・ M ・エーデルマン：脳は空より広い か「私」という現象を考える. 草思社, 東京, 2006, 120-136 頁.

11）豊福 明：いわゆる口腔心身症の入院治療について の臨床的研究一治療技法の検討と病態仮説の構築 について一. 日柬心身 15: 41-71 2000.

12）豊福 明，梅本丈二，他：柬科心身症の入院治療と その遠隔成績について. 日柬心身 19: 37-42 2004.

13）松田博史：PET, SPECT. 福田正人 責任編集 精 神疾患と脳画像, 中山書店, 東京, 2008, 34-44 頁.

14) Brendan, M.: Personal genomes: The case of the missing heritability. Nature 456: 18-21 2008.

15）豊福 明, 都 温彦：「うつと不安一進歩した薬 物療法」歯科口腔外科疾患における歯科心身症の変 化と新規薬剤の使用経験. 臨床と研究 80: 1636-1640 2003.

16）都 温彦：心身医学的アプローチによる舌疼痛症治 療への方向付け, 柬展 43: 1037-1042 1974.

17) Patton, L.L., Sieqel, M.A., et al.: Management of burning mouth syndrome: systemic review and management recommendations. Oral Surg Oral Med Oral Pathol Oral Radiol Endod103 (suppl 1): S39. e1-S39. e13 2007.

18）豊福 明：“柬科心身症”としての舌痛症, 日柬心 身 21: 43-48 2006.

19) Finniss, D.G. and Benedetti, F.: Placebo Analgesia, Nocebo Hyperalgesia. PAIN: Clinical Update Vol XV, 1-4, March 2007.

20) Stahl, S.M.: Antidepressants and somatic symptoms: Therapeutic actions are expanding beyond affective spectrum disorders to functional somatic syndromes. J Clin Psychiatry 64: 745-746 2003.

21) Maina, G., Vitalucci, A., et al.: Comparative Efficacy of SSRIs and Amisulpride in Burning Mouth Syndrome:A Single-Blind Study. J Clin Psychiatry 63: 38-43 2002.

22) Maina, G. and Bogetto, F.: Dr. Maina and Bogetto Reply. J Clin Psychiatry 64: 337-338 2003.

23) 豊福 明, 都 温彦: 各診療科での抗不安薬治療の 実際 一 症例提示 - 11. 柬科口腔外科 Modern Physician 24: 1091-1094 2004.

24）ハーブ・カチンス，スチュワート・A・カーク：精 神疾患はつくられる一DSM 診断の罠一. 日本評論 社, 東京, 2002.

25）豊福 明：柬科心身症への新しいアプローチ. 口病 誌 74: 161-168 2007. 